The Journal of Animal \& Plant Sciences, 31(1): 2021, Page: 254-264

ISSN (print): 1018-7081; ISSN (online): 2309-8694

\title{
ARE SUPPORT POLICIES FOR SUSTAINABLE LIVESTOCK IMPORTANT? CAUSALITY BETWEEN ANIMAL EXISTENCE AND SUPPORT POLICIES: VECM ANALYSIS FOR TURKEY
}

\author{
H. Erdal ${ }^{1}$, G. Erdal ${ }^{*}$ and B. Ayyildiz ${ }^{3}$ \\ ${ }^{1}$ Department of Management and Organization, Social Sciences Vocational School, Tokat Gaziosmanpasa University, \\ Tokat- TURKEY \\ ${ }^{2}$ Department of Agricultural Economics, Faculty of Agriculture, Tokat Gaziosmanpasa University, Tokat-TURKEY \\ ${ }^{3}$ Yozgat Bozok University Agriculture Faculty, Agricultural Economics Department, Yozgat/TURKEY \\ "Corresponding author's e-mail: gulistan.erdal@gop.edu.tr
}

\begin{abstract}
Parallel to the ever-increasing world population, the demand for animal-derived protein is also increasing. Countries are reviewing animal production growth and development to cover the increasing demand for animal-derived protein. On the other hand, there are intense discussions regarding the protection of the natural resource base and the global environment. The Agricultural Organization (FAO), is considering the concerns at the focus of the discussions, is developing strategies and policy proposals, especially in developing countries, on issues regarding sustainable animal agriculture. In this case, generally, agriculture policies of countries and livestock support policies in particular are important. In addition, the supports are a driving force in the development of animal genetics, increasing the number of animals, development of animal breeds, and enhancing animal welfare. For Turkey, which has a large and growing population, this issue is very important. It is noteworthy in terms of the support for animal production to provide sustainable livestock in Turkey, especially in agricultural policies. In this sense, as a primary target in Turkey, to accelerate the animal presence, a systematic and increasing rate of support payments per animal have been realized since 2000s. In the present study, it was investigated whether livestock support policies had effects on ensuring sustainable livestock in Turkey, moreover the presence of a causality relation between animal presence and support policies was also examined. The Vector Error Correction Model (VECM) was employed to explain the causal relationships. The analyses were applied to the panel dataset for the period of 2004-2014 at the European Union regional statistics system (Nomenclature d'Unités Territoriales Statistiques (NUTS) Level 2 (26 sub-regions) regions. According to VECM results, a bilateral causality was determined between the support payments applied in the short term and animal presence. The result showed that livestock support policies implemented in Turkey is important for the sustainability of animal production. The geographical conditions and the level of economic development of each region in Turkey must be considered, and special support items must be provided at the regional level.
\end{abstract}

Keywords: Sustainable Livestock, Support Policies, Animal Existence, VECM Analysis, Causality.

https://doi.org/10.36899/JAPS.2021.1.0212

Published online August 26, 2020

\section{INTRODUCTION}

Livestock contribute $40 \%$ of the global value of agricultural output and support the livelihoods and food security of almost a 1.3 billion people. The livestock sector is one of the fastest growing parts of the agricultural economy Livestock is a tool for recycling the nutrients and serves as an energy source and value-added production. Its complementary roles in the agricultural system are unique and must be used fully. The growth and transformation of the sector offer opportunities for agricultural development, poverty reduction and food security gains, but the rapid pace of change risks marginalizing smallholders, and systemic risks to the natural resources and human health must be addressed to ensure sustainability. (FAO,2020). However, there is consensus among politicians, planners, and scientists that livestock production in developing countries is not growing rapidly at an adequate level to cover the needs of the growing world population. The growth in the animal products in these countries was a result of increased animal populations rather than largely increased productivity (FAO, 2017).

Throughout years, although there have been many development projects carried out by bilateral and multilateral institutions - often with significant capital investment -, there was little change in the efficiency or sustainability of animal production in the developing world (FAO, 2019). On the other hand, livestock farming has a vast environmental footprint. It contributes to land and water degradation, biodiversity loss, acid rain, coral reef degeneration and deforestation. Nowhere is this impact more apparent than climate change - livestock 
farming contributes $18 \%$ of human produced greenhouse gas emissions worldwide (Steinfeld et al., 2006).

When growing concerns about the protection of the natural resource base and the protection of the global environment are considered, the Food and Agriculture Organization (FAO) gave the highest priority to the sustainable development of both plants and animal farming in the world. One of the initiatives of the organization was a number of expert interviews in developing countries to examine issues regarding sustainable animal agriculture. It was concluded in this consultation that strategies for sustainable livestock production had to deal with areas like protecting the resource base, minimizing waste and maximizing food recovery and production per source. In addition, FAO is also working to provide strategies for national governments to develop sustainable livestock and recommendations for the necessary policy framework (FAO, 2014). There were significant changes and improvements in agricultural production in Turkey in the past years. In this process, different policies and support means were implemented in terms of the development and sustainability of livestock production. In this process, the purpose was to ensure the interaction of many repulsive forces with each other in terms of the sustainability of livestock (Zanten et al 2016).

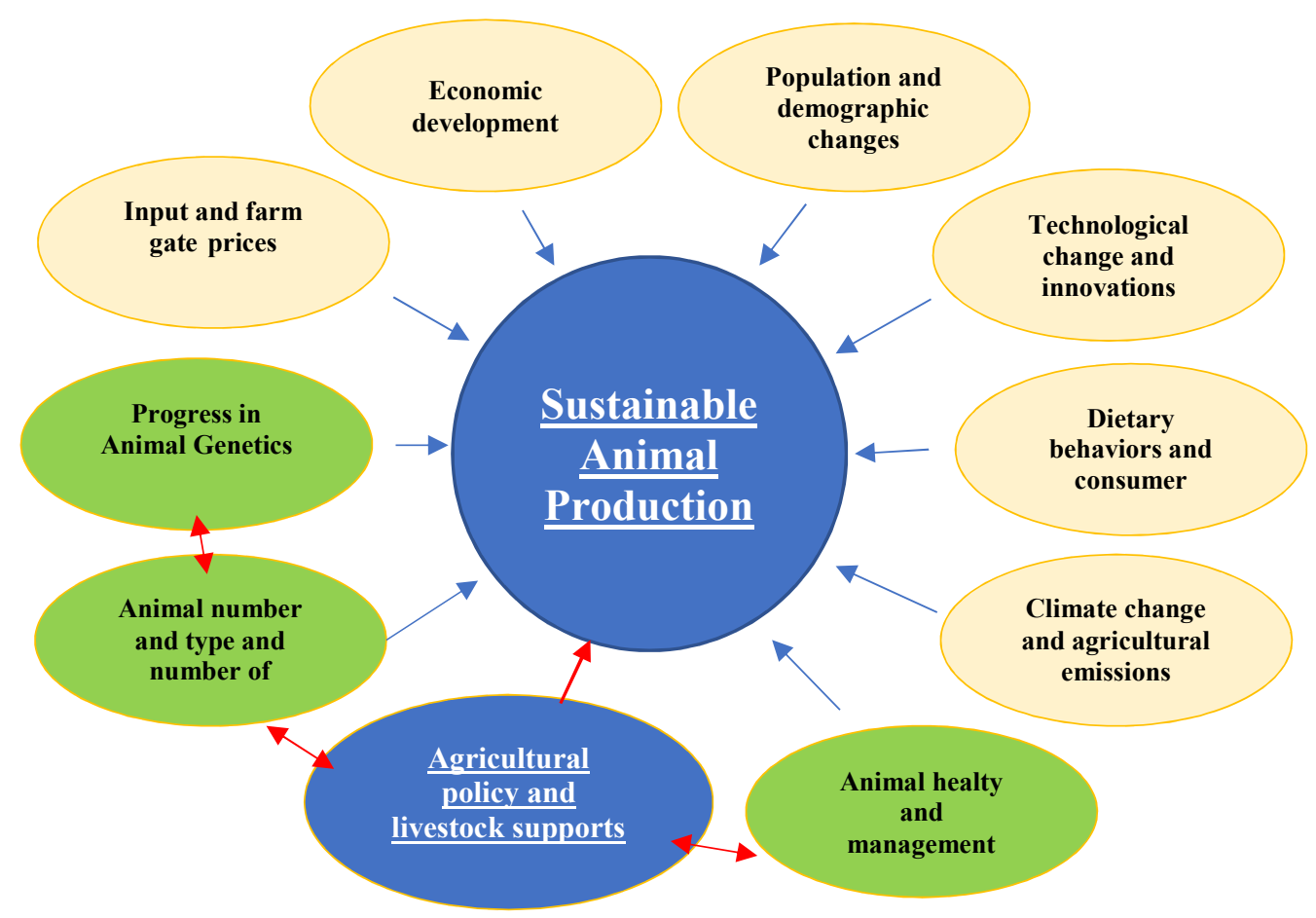

Figure 1. Different variables affecting the sustainability of livestock (Zanten et al.,2016; Babette et al.,2019).

Factors like economic development, population and demographic changes, technological change, animal health, environmental issues, and agricultural policy are key factors that enable the change and modulation of the livestock (Figure 1). The economic development, population structure, technological changes and developments of a country have an indirect effect on the sustainability of livestock production, and the number of animals and race, animal health, agricultural policies, and livestock supports have direct effects. Here, agricultural policies and supports for animal production, which play important roles in ensuring sustainable livestock production, are also repulsive in the development of animal genetics, the number of animals, and the development of animal breeds and in the increase in animal welfare constitutes a power.

In this respect, the supports provided to livestock production in Turkey, especially in agricultural policies, play important roles in ensuring sustainable livestock production. When the animal-derived protein consumption values in Turkey over time were evaluated, it was seen that it increased by about 12 gr in 2013 (29,81gr) compared to 1967 (17,89gr) (50 years ago) (FAOSTAT, 2019). When the different types of animal protein are considered, it is seen that egg consumption has remained relatively constant in time, but milk consumption increased slightly by 4 grams in last 50 years. However, most of the variations in animal protein consumption occur because of the variations in meat 
consumption. The steady increase in meat consumption until 1986 was related with beef and mostly poultry consumption. Later, poultry consumption continued to increase until 2009, but beef consumption declined. In these years, sheep and goat meat consumption continued to decrease. Therefore, it can be said that the significant increase in total meat consumption is provided by poultry meat consumption (FAOSTAT, 2019). The instability ower time variation in beef, mutton and poultry meat consumption is related to decrease or increase in the number of these animals, as shown in Figure 2.

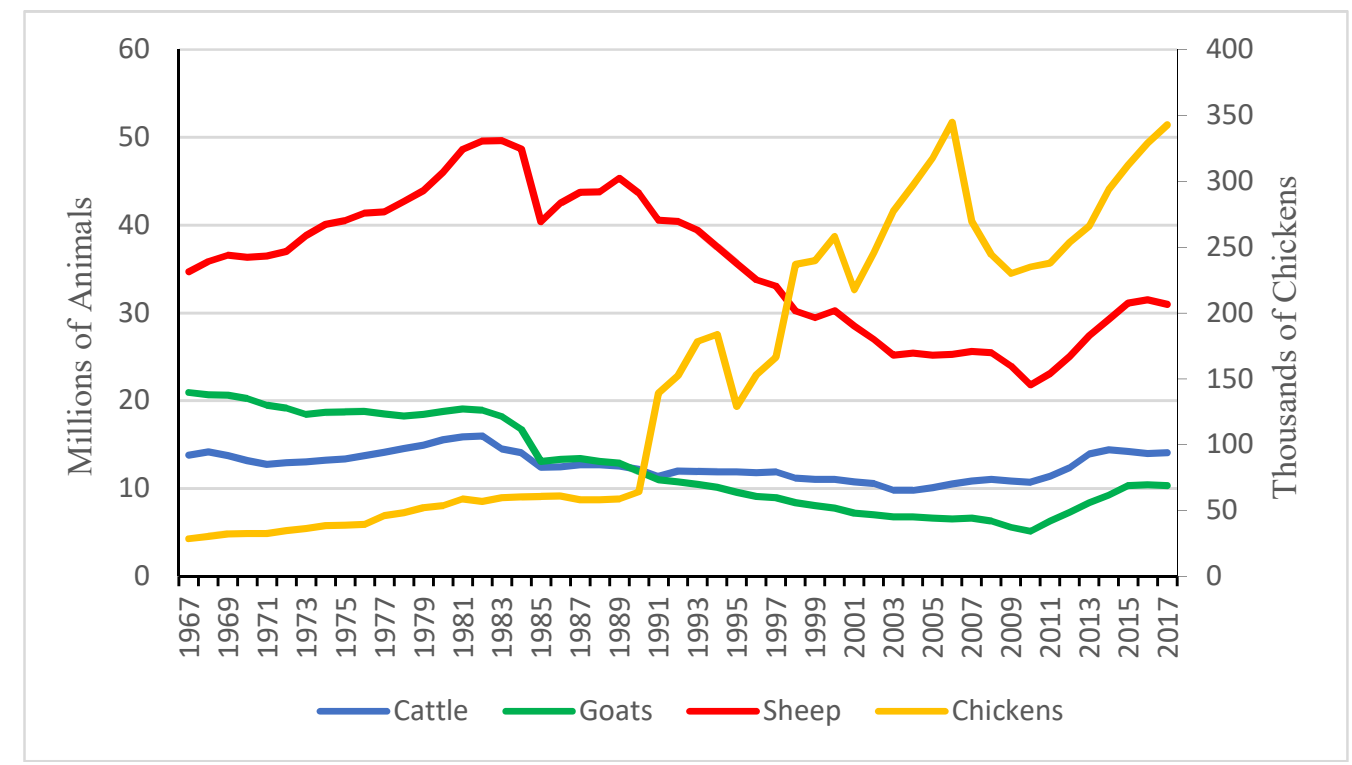

Figure 2. Amount of production animals in Turkey from 1967 to 2017 (FAOSTAT, 2019).

The number of cattle increased to 14 million in 2017 from 13.8 million in 1967 in Turkey. Again, the number of goats, which was 20 million, decreased at a rate of $50 \%$ to 10 million in the same years. The amount of sheep decreased from 50 million in 1983 to 30 million in 2017. These decreases in all these animal counts activate poultry in meeting the increasing demand for animal protein. As can be seen, the number of poultries increased quite rapidly (Figure 2). On the other hand, Turkey has experienced a fast increase in its population size in the last 50 years, which will continue to increase in the next 50 years (FAOSTAT, 2019). The population of the country, which was 81 million in 2017 , is predicted to be 92.8 million in 2037, and 97.9 million in 2057. The population of the world continues to grow like in Turkey. Although the predictions of the future population of the world are variable and vague, estimates show that the world population will exceed 9.7 billion by 2050 (UN, 2019).

For this reason, even if the population growth in Turkey and global population growth stops during this century, the demand for food will increase continuously.

As of the early 2000s, Turkey tried to supports livestock by making changes in agricultural policies to cover the need of the increasing population and increasing protein demand, and to make livestock sustainable. In this respect, livestock support policies were revised as of 2000, and new decisions were taken according to the needs to ensure sustainability. In these regulations, measures for race breeding, increasing coarse feed production, increasing productivity, specialization and modernization of the existing enterprises, waste control, animal healthcare, and welfare in livestock activities were experienced (Demir, 2009). It is seen that with these measures strategies for sustainable livestock taken by the FAO were considered (i.e. protecting the resource base, minimizing waste and maximum food gain). With the following changes, the share of livestock support payments in Turkey was increased from $1.5 \%$ in 2002 to $20 \%$ in 2010, and about 30\% for 2015 (Turkey's Ministry of Finance, 2016).

As it is mentioned above, there has been a systematic and increasing support payment policy application in 2000s whereas there was no large scale and stable livestock support policy in general. An increase has been seen in animal existence with the livestock support payments in 2000s. Especially between the years $1991-2000$ there had been a $10.4 \%$ decrease in cattle and $32.5 \%$ decrease in small cattle population but a $35.4 \%$ increase in cattle and $11.5 \%$ small cattle population has been seen between the years 2000-2015 (Figure 2). It can be said that the animal existence changed into fertile races with the support payment requirements, which has been being applied since 2009, of culture and culture hybrid race animals. Total cattle population in Turkey has increased to 14 million by 2015 and approximately $46 \%$ 
of it consists of culture races and $13 \%$ of it is native race animals (TURKSTAT, 2015).

It is noticed that statistical analyses were carried out in some studies about livestock support policies in Turkey (Ertuğrul, 2000; Gültek, 2000; Ören and Bahadır, 2005; Tan, 2015; Saghir et al., 2016, Peker et al., 2019) and in field studies(Aksu and Dellal, 2016; Ata and Yllmaz, 2015; Demir and Yavuz, 2010, Riasat et al., 2014; Saman et al.,2017; Doğan and Altuntaş, 2017). the analyses were focused on a selected policy means. In a different study titled "Policies for Livestock Development in the Ethiopian Highlands" (Benin et al., 2003), it is stated as the result of the study, which was carried out in 98 villages, that livestock raising had declined despite the increased adaptation of animal health services and animal feeding improvements into regional policies. The study also stated that to prevent this situation, credit association among enterprises should be set, livestock breeding activities should be improved, population control should be carried out, the poorness of agricultural enterprises especially in East Africa should be resolved and policies concerning the food safety should be operated. In their study of questionnaire with a total of 4500 enterprise owners in England, Germany, and Portugal, (Daugbjerg et al., 2005) analysed the perception of enterprise owners on supports of Common Agricultural Policy and the effects of these policies. It was determined that enterprise owners perceive the supports even though they have incomplete information about them. There is only one study found in the literature that is concerning the effects support policies on livestock sector in Turkey on a regional basis. This study analysed the effects of support policies applied between 2005-2007 in Western Marmara and Northeast Anatolia regions (Demir, 2009).

In the present study, the effect of animal husbandry support policies implemented in Turkey with the purpose of achieving an increase in animal production was investigated. In this respect, we considered the increase in animal production as an increase in the animal presence and analyzed the relations between support payments using VEC Model. Turkey 26 sub-regional level is evaluated in the study with the European Union regional statistics system (Nomenclature d'Unités Territoriales Statistiques (NUTS). In this way, we evaluated the changes at the level of livestock by regional differences formed by the geographical structure of the country and the level of development of the provinces. We could discuss the difference in the distribution or use of support payments at the regional level and comment all over Turkey. We believe that the findings of our study are statistically important for the functioning of existing policies and that the results will show the importance of sustainable livestock supporting policies.

\section{MATERIALS AND METHODS}

The present study used secondary data. The data were obtained from different sources like official statistics records of Turkish Statistical Institute (TURKSTAT, 2015) and Ministry of Food, Agriculture and Livestock (MFAL, 2016). MFAL and Official Newspaper sources were used to gather information about the livestock sector supports and promotions (MFAL, 2016; Newspaper of Turkey, 2015; Official Newspaper of Turkey, 2016).

The study used panel data set. The cross section of the panel consisted all of the 26 sub-regions in NUTS Level 2 of nomenclature of territorial units for statistics. The data for the period of 2004 to 2014 was used, as livestock supports were intensively applied between these years in the study area. Livestock support payments in different items and cattle population numbers were used as variables for each of the region in the relevant period.

Data Analysis: The analyses of the data were carried out with E-views 7, statistics packet programme.

Each variable was tested for stationary test, (unit root test), in the first part of the analyses. The studies of (Levin et al., 2002; Im et al., 2003; Maddala and $\mathrm{Wu}$, 1999) are the major studies which used unit root test in panel data sets. This study followed the approach used by Levin et al (2002). The appropriate lag lengths which eliminate the autocorrelation problem between errors were selected according to Schwars Information Criterion. After unit root tests, Kao cointegration analysis was carried out to investigate if there is an interrelation between series in long term. Kao presented a cointegration analysis test which uses DF and ADF tests to analyse panel data in 1999 (Baltagi et al., 2000; Asteriou and Hall, 2007).

Engle and Granger combined cointegration and error correction models, to establish the trace error correction model. As long as there is a cointegration relationship between variables, the error correction model can be derived from the autoregressive distributed lag model. And each equation in the Vector autoregression (VAR) model is an autoregressive distributed lag model; therefore, it can be considered that the Vector Error Correction model (VECM) is a VAR model with cointegration constraints. Because there is a cointegration relationship in the VEC model, when there is a large range of short-term dynamic fluctuation, VEC expressions can restrict long-term behavior of the endogenous variables and be convergent to their cointegration relation.

A causality analysis was carried out to identify the direction of the relationship between variables and to test them for short and long term. Vector Error Correction Model (VECM) for this analysis. The direction of the relationship can be identified when two variables are 
cointegrated. The error correction model can be formulized

$$
\begin{aligned}
& \Delta \mathrm{Y}_{i t}=\delta_{1 i}+\sum_{p=1}^{k} \delta_{11 i p} \Delta \mathrm{Y}_{i t-p}+\sum_{p=1}^{k} \delta_{12 i p} \Delta \mathrm{X}_{i t-p}+\varphi_{1 i} \hat{\varepsilon}_{i t-1}+v_{1 i t} \\
& \Delta \mathrm{X}_{i t}=\delta_{2 i}+\sum_{p=1}^{k} \delta_{21 i p} \Delta \mathrm{X}_{i t-p}+\sum_{p=1}^{k} \delta_{22 i p} \Delta \mathrm{Y}_{i t-p}+\varphi_{2 i} \hat{\varepsilon}_{i t-1}+v_{2 i t}
\end{aligned}
$$

as

follows:

k stands for optimal lag length (lengths). $\hat{\varepsilon}_{i t}$ shows the residual (residuals) terms. This description enables analysing both for short- and long-term causality relationships. Wald test was used to analyse the shortterm causality relationships between variables. The longterm causality relationship was analysed by studying the significance of the test statistics of error correction coefficient $(\varphi)(\mathrm{ECT})$.

\section{RESULTS AND DISCUSSION}

\section{Relationships Between Support Policies and Animal} Existence: In this part of the study, animal population numbers, support amount per animal (between 20092014) calf support, milk support, forage plants support and total livestock support data were collected for $26 \mathrm{sub}$ regions in NUTS Level 2 of nomenclature of territorial units for statistics. The shares of these items in average current values for variables of 11 years and average current values of Turkey were calculated (Table 1).

When we focus on the regional values of average livestock support payments in Turkey between the years 2004-2014, it is seen that the largest payment value in total livestock support belongs to TR22 area (Balıkesir and Çanakkale - South Marmara). The share of the TR22 region in brood cattle support payment in Turkey is $11,27 \%$. The biggest share of the region in the support items is in milk support (16.41\%). TR22 region is followed by TR32 and TR31 sub regions which are in Aegean borders. It is significantly remarkable that TRA2 A ğrı, Kars, Iğdır, Ardahan sub region has a share of $4.36 \%$ from total support payments even though the animal population recorded the highest according to the average values of 11 years. Other eastern regions also show similar results. TR83 region (Samsun, Tokat, Çorum, Amasya) showed a moderate situation with a 5\% share from total livestock support payments. This region has a bigger animal population than TR22, TR32 and TR31 areas yet its share from support payments is lower. In forage plants support, the biggest share belongs to TRA2 (Ağrı, Kars, Iğdır, Ardahan) sub region by $11.63 \%$ followed by TR83 region with a share of $7.45 \%$. The smallest share from total livestock support payments was $0.48 \%$ and belongs to TR90 (Trabzon, Ordu, Giresun, Rize, Artvin, Gümüşhane) region.
It is a fair starting point to investigate "broad cattle support" among the support item requirements, which was started to be given in 2009 and repealed in 2015 with the condition "the animal to be supported have to be from either a culture or a hybrid race"(Official Newspaper of Turkey, 2015; Official Newspaper of Turkey, 2016) in order to explain the utilisation rate differences of the regions. As it is clear from the condition that native race animals were not supported. It is known that native race population is higher than other in the eastern and some of the central regions of Turkey. This fact prompts the question that if the lower support payment shares of those regions are caused by the races of the animals. On the other hand, calf support was tied to the condition of being born from culture or hybrid races by the way of artificial insemination or from ministryapproved bulls by natural insemination. For this reason, the situation was evaluated taking prominent regions by their animal existence numbers and shares from support payments (Table 1). The animal populations of culture, hybrid and native races of the a fore mentioned regions were determined for the years of 2004 to 2014 and their shares from total livestock support payments were calculated. The change in the population of supportable races and in the shares from the support payments would be clearly visible by this way (Table 2).

As livestock support payments are available both for culture and hybrid races, it is important to take those two races into consideration together. It can be seen in the examples (Table 2) that there is a 3 to 7 times increase in culture race between 2004 to 2014, and 1 to 3 times increase can be seen in hybrid race except TR31 and TR32 regions. On the contrary, native race cattle population has decreased in approximately all of the regions. However, there is no proportional difference among regions in terms of current races. The culture race ratio is higher in western regions such as TR22, TR31 and TR32 and in some central regions such as TR52 and TR71, whereas hybrid race ratio is higher in the rest, which is a significant statistical detail. A noteworthy parameter causing the increase of the population of these two races is that support payment per animal is intended to be given for culture and hybrid races. Furthermore, production support for stock farming (brood cattle and calf) and donation support for livestock breeding in provinces in GAP, DAP, DOKAP and KOP areas are especially important. 
Table 1- Animal Existence of Turkey and NUTS Level 2 Regions and Some of the Support Items (average current values of 2004-2014).

\begin{tabular}{|c|c|c|c|c|c|c|c|c|}
\hline CODE & $\begin{array}{l}\text { NUTS Level } 2 \text { (26 Sub } \\
\text { Regions) }\end{array}$ & & $\begin{array}{c}\text { Cattle } \\
\text { Population } \\
\text { (number) } \\
\end{array}$ & $\begin{array}{c}\text { Forage Plants } \\
\text { Support } \\
\text { (Turkish Liras) } \\
\end{array}$ & $\begin{array}{c}\text { Calf Support } \\
\text { (Turkish } \\
\text { Liras) } \\
\end{array}$ & $\begin{array}{l}\text { Milk Support } \\
\text { (Turkish Liras) }\end{array}$ & $\begin{array}{c}\text { Brood Cattle } \\
\text { Support } \\
\text { (Turkish Liras) } \\
\end{array}$ & $\begin{array}{c}\text { Total Livestock } \\
\text { Support } \\
\text { (Turkish Liras) } \\
\end{array}$ \\
\hline \multirow{2}{*}{ TR10 } & \multirow{2}{*}{ İstanbul } & avg. & 70.563 & 942.924 & 473.436 & 1.504 .468 & 3.791 .292 & 5.814 .452 \\
\hline & & $\%$ & 0,59 & 0,31 & 0,94 & 0,50 & 0,95 & 0,58 \\
\hline \multirow{2}{*}{ TR21 } & Tekirdăg, Edirne, & avg. & 412.269 & 8.528 .421 & 4.361 .257 & 29.916 .786 & 31.803 .370 & 67.316 .353 \\
\hline & Kırklareli & $\%$ & 3,45 & 2,82 & 8,64 & 9,91 & 7,97 & 6,76 \\
\hline \multirow{2}{*}{ TR22 } & \multirow{2}{*}{ Balıkesir, Çanakkale } & avg. & 613.827 & 14.889 .391 & 5.332 .380 & 49.561 .207 & 44.981 .544 & 103.934 .634 \\
\hline & & $\%$ & 5,13 & 4,92 & 10,56 & 16,41 & 11,27 & 10,44 \\
\hline \multirow{2}{*}{ TR31 } & \multirow{2}{*}{ İzmir } & avg. & 396.082 & 17.713 .685 & 4.139 .620 & 33.394 .591 & 32.163 .349 & 77.869 .982 \\
\hline & & $\%$ & 3,31 & 5,85 & 8,20 & 11,06 & 8,06 & 7,82 \\
\hline \multirow{2}{*}{ TR32 } & \multirow{2}{*}{ Aydın, Denizli, Muğla } & avg. & 619.627 & 20.337 .310 & 5.210 .671 & 32.067 .778 & 37.185 .349 & 86.776 .308 \\
\hline & & $\%$ & 5,18 & 6,72 & 10,32 & 10,62 & 9,31 & 8,72 \\
\hline \multirow{2}{*}{ TR33 } & \multirow{2}{*}{$\begin{array}{c}\text { Manisa, Afyonkarahisar, } \\
\text { Kütahya, Uşak }\end{array}$} & avg. & 731.833 & 16.901 .082 & 3555257 & 25.930 .743 & 29.983 .748 & 73.093 .858 \\
\hline & & $\%$ & 6,12 & 5,58 & 7,04 & 8,59 & 7,51 & 7,34 \\
\hline \multirow{2}{*}{ TR41 } & \multirow[t]{2}{*}{ Bursa, Eskişehir, Bilecik } & avg. & 322.265 & 9114516 & 2482358 & 15.153 .220 & 16.238 .424 & 40.085 .244 \\
\hline & & $\%$ & 2,70 & 3,01 & 4,92 & 5,02 & 4,07 & 4,03 \\
\hline \multirow{2}{*}{ TR42 } & \multirow{2}{*}{$\begin{array}{c}\text { Kocaeli, Sakarya, Düzce, } \\
\text { Bolu, Yalova }\end{array}$} & avg. & 412.165 & 8.197 .841 & 2.008 .867 & 8.648 .539 & 15.175 .310 & 30.863 .064 \\
\hline & & $\%$ & 3,45 & 2,71 & 3,98 & 2,86 & 3,80 & 3,10 \\
\hline \multirow{2}{*}{ TR51 } & \multirow{2}{*}{ Ankara } & avg. & 245.912 & 2.019 .100 & 551.825 & 2.005 .305 & 3.444 .878 & 12.166 .589 \\
\hline & & $\%$ & 2,06 & 0,67 & 1,09 & 0,66 & 0,86 & 1,22 \\
\hline \multirow{2}{*}{ TR52 } & \multirow{2}{*}{ Konya, Karaman } & avg. & 514.888 & 14.529 .622 & 3.032 .222 & 28.112 .101 & 32.590 .249 & 74.305 .450 \\
\hline & & $\%$ & 4,31 & 4,80 & 6,00 & 9,31 & 8,16 & 7,46 \\
\hline \multirow{2}{*}{ TR61 } & \multirow{2}{*}{ Antalya, Isparta, Burdur } & avg. & 382.669 & 6.969 .650 & 3.827 .630 & 22.100 .931 & 25.695 .320 & 53.514 .948 \\
\hline & & $\%$ & 3,20 & 2,30 & 7,58 & 7,32 & 6,64 & 5,38 \\
\hline \multirow{2}{*}{ TR62 } & \multirow{2}{*}{ Adana, Mersin } & avg. & 290.030 & 6.946 .809 & 1.969 .252 & 5.318 .014 & 10.233 .281 & 22.577 .110 \\
\hline & & $\%$ & 2,43 & 2,30 & 3,90 & 1,76 & 2,56 & 2,27 \\
\hline \multirow{2}{*}{ TR63 } & \multirow{2}{*}{$\begin{array}{c}\text { Hatay, Kahramanmaraş, } \\
\text { Osmaniye }\end{array}$} & avg. & 301.391 & 8.819 .428 & 832.081 & 4.454 .658 & 8.284 .110 & 22.141 .767 \\
\hline & & $\%$ & 2,52 & 2,91 & 1,65 & 1,48 & 2,07 & 2,22 \\
\hline \multirow{2}{*}{ TR71 } & \multirow{2}{*}{$\begin{array}{c}\text { Kırıkkale, Aksaray, Niğde, } \\
\text { Nevşehir, Kırşehir }\end{array}$} & avg. & 394.278 & 9.834 .671 & 2.973 .218 & 22.143 .810 & 25.159 .391 & 54.880 .982 \\
\hline & & $\%$ & 3,30 & 3,25 & 5,89 & 7,33 & 6,30 & 5,51 \\
\hline TR72 & Kayseri, Sivas, Yozoat & avg. & 771.920 & 15.612 .297 & 1.233 .202 & 4.743 .331 & 12.152 .092 & 35.463 .186 \\
\hline $1 \times 12$ & nayser, Sivas, Yozgat & $\%$ & 6,46 & 5,16 & 2,44 & 1,57 & 3,04 & 3,56 \\
\hline TR81 & Zonguldak, Karabük, & avg. & 181.697 & 1.917 .998 & 311.594 & 898136 & 1.609 .089 & 4.793 .452 \\
\hline $1 \mathrm{KOI}$ & Bartın & $\%$ & 1,52 & 0,63 & 0,62 & 0,30 & 0,40 & 0,48 \\
\hline TR82 & Kastamonu, Cankırı, Sinop & avg. & 456.135 & 11.308 .765 & 1.757 .049 & 2.182 .676 & 12.391 .706 & 24.278 .690 \\
\hline $1 \mathrm{KO} 2$ & Rastamonu, ÇäkIrI, SIIIOp & $\%$ & 3,82 & 3,74 & 3,48 & 0,72 & 3,10 & 2,44 \\
\hline TR83 & Samsun, Tokat, Çorum, & avg. & 892.285 & 22.561 .886 & 2.584 .478 & 4.893 .017 & 17.783 .653 & 47.655 .216 \\
\hline
\end{tabular}




\begin{tabular}{|c|c|c|c|c|c|c|c|c|}
\hline & Amasya & $\%$ & 7,46 & 7,45 & 5,12 & 1,62 & 4,45 & 4,79 \\
\hline \multirow{2}{*}{ TR90 } & Trabzon, Ordu, Giresun, & avg. & 507.608 & 893.008 & 706.150 & 1.067 .550 & 2.024 .840 & 4.752 .026 \\
\hline & Rize, Artvin, Gümüșhane & $\%$ & 4,25 & 0,30 & 1,40 & 0,35 & 0,51 & 0,48 \\
\hline \multirow{2}{*}{ TRA1 } & Erzurum, Erzincan, & avg. & 726.048 & 14.695 .706 & 563.317 & 731.195 & 7.594 .603 & 23.601 .763 \\
\hline & Bayburt & $\%$ & 6,07 & 4,86 & 1,12 & 0,24 & 1,90 & 2,37 \\
\hline \multirow{2}{*}{ TRA2 } & & avg. & 1.047 .057 & 35.195 .158 & 627.636 & 1.619 .152 & 8.673 .669 & 43.450 .037 \\
\hline & Ağrı, Kars, Iğdır, Ardahan & $\%$ & 8,76 & 11,63 & 1,24 & 0,54 & 2,17 & 4,36 \\
\hline \multirow{2}{*}{ TRB1 } & Malatya, Elazı ̌̆, Bingöl, & avg. & 350.008 & 7.705 .675 & 601.561 & 717.050 & 4.700 .631 & 16.235 .442 \\
\hline & Tunceli & $\%$ & 2,93 & 2,55 & 1,19 & 0,24 & 1,18 & 1,63 \\
\hline \multirow{2}{*}{ TRB2 } & & avg. & 541.427 & 29.933 .145 & 389.521 & 427.557 & 4.084 .212 & 35.043 .794 \\
\hline & Van, Muş, Bitlis, Hakkari & $\%$ & 4,53 & 9,89 & 0,77 & 0,14 & 1,02 & 3,52 \\
\hline \multirow{2}{*}{ TRC1 } & & avg. & 160.838 & 3.737 .319 & 361.876 & 2.246 .808 & 3.707 .830 & 10.680 .817 \\
\hline & Gaziantep, Adiyaman, Kilis & $\%$ & 1,35 & 1,23 & 0,72 & 0,74 & 0,93 & 1,07 \\
\hline \multirow{2}{*}{ TRC2 } & & avg. & 442.792 & 4.610 .542 & 219.615 & 988.453 & 4.849 .763 & 12.206 .201 \\
\hline & Şanlıurfa, Diyarbakır & $\%$ & 3,70 & 1,52 & 0,43 & 0,33 & 1,21 & 1,23 \\
\hline \multirow{2}{*}{ TRC3 } & Mardin, Batman, Şırnak, & avg. & 168.423 & 8.729 .176 & 260.124 & 808.259 & 2.969 .128 & 12.034 .398 \\
\hline & Siirt & $\%$ & 1,41 & 2,88 & 0,52 & 0,27 & 0,74 & 1,21 \\
\hline \multirow[t]{2}{*}{ TR } & TURKEY & avg. & 11.954 .039 & 302.645 .126 & 50.500 .726 & 301.971 .689 & 399.270 .830 & 995.535 .764 \\
\hline & \multicolumn{3}{|c|}{ Real average values in Turkey in general } & 183.626 .624 & 27.903 .630 & 168.899 .653 & 196.061 .754 & 553.366 .744 \\
\hline
\end{tabular}

Table 2 - Animal Existence and Livestock Support Shares

\begin{tabular}{|c|c|c|c|c|c|c|c|c|c|}
\hline \multirow[t]{2}{*}{ Code } & \multirow[t]{2}{*}{ NUTS Level 2, Sub-region } & \multicolumn{2}{|c|}{$\begin{array}{c}\text { Culture Race } \\
\text { (number) }\end{array}$} & \multicolumn{2}{|c|}{$\begin{array}{c}\text { Hybrid Race } \\
\text { (number) }\end{array}$} & \multicolumn{2}{|c|}{$\begin{array}{c}\text { Total Livestock } \\
\text { Support Share }(\%)\end{array}$} & \multicolumn{2}{|c|}{$\begin{array}{c}\text { Native Race } \\
\text { (number) }\end{array}$} \\
\hline & & 2004 & 2014 & 2004 & 2014 & 2004 & 2014 & 2004 & 2014 \\
\hline TR22 & Balıkesir, Çanakkale & 234.740 & 604.766 & 44.886 & 115.693 & 9,46 & 10,24 & 19.908 & 36.249 \\
\hline TR31 & İzmir & 126.899 & 424.945 & 107.338 & 110.380 & 6,40 & 8,56 & 29.850 & 20.590 \\
\hline TR32 & Aydın, Denizli, Muğla & 152.924 & 543.169 & 222.163 & 140.165 & 7,00 & 9,22 & 99.789 & 57.829 \\
\hline TR52 & Konya, Karaman & 142.538 & 508.902 & 169.749 & 248.062 & 6,89 & 9,20 & 50.887 & 52.737 \\
\hline TR71 & Kırıkkale, Aksaray, Niğde, Nevşehir, Kırşehir & 93.860 & 306.667 & 140.179 & 231.904 & 4,50 & 6.77 & 51.610 & 33.108 \\
\hline TR72 & Kayseri, Sivas, Yozgat & 121.421 & 323.978 & 355.840 & 456.646 & 4,84 & 3,62 & 79.208 & 86.861 \\
\hline TR83 & Samsun, Tokat, Çorum, Amasya & 90.844 & 281.191 & 362.225 & 457.863 & 7,95 & 4,52 & 336.414 & 225.273 \\
\hline TRA1 & Erzurum, Erzincan, Bayburt & 43.151 & 120.569 & 289.048 & 630.123 & 2,50 & 2,01 & 354.916 & 69.531 \\
\hline TRA2 & Ăgrı, Kars, Ĭgdır, Ardahan & 47.841 & 138.269 & 309.548 & 855.891 & 1,20 & 3,09 & 354.916 & 275.078 \\
\hline TRB1 & Malatya, Elazı̆̆, Bingöl, Tunceli & 46.914 & 133.890 & 157.469 & 251.113 & 1,99 & 1,33 & 105.654 & 65.526 \\
\hline TRC2 & Şanlıurfa, Diyarbakır & 19.292 & 144.410 & 79.339 & 245.260 & 1,70 & 1,60 & 275.444 & 200.012 \\
\hline TR90 & $\begin{array}{l}\text { Trabzon, Ordu, Giresun, Rize, Artvin, } \\
\text { Gümüşhane }\end{array}$ & 56.198 & 108.269 & 275.902 & 293.730 & 0,73 & 0,37 & 209.358 & 91.345 \\
\hline TR & Turkey & 2.109 .393 & 6.178 .757 & 4.395 .090 & 6.060 .937 & - & - & 3.564 .863 & 1.983 .415 \\
\hline
\end{tabular}


Utilization ratio of the regions in terms of support payments is quite different from each other although the support payments are applied equally for all regions. TR22 region took a share of $9.46 \%$ from the supports with its culture and hybrid race animal existence in 2004 however in the same year, the share of TRA2 region from the supports was $1.20 \%$. The culture and hybrid race animal existence of TRA2 was bigger than the amount of TR22. Similar situations are true for regions such as TR72, TRA1, TRB1 AND TRC2. On the other hand, TR83 region showed a 63\% increase in 2014 in comparison with 2004, yet its share from total supports decreased.

It is known that there are differences among regions in terms of meat and milk yield despite the equal application of support policies in all regions. The difference in yield of the culture race can be understood more clearly when the average milk yield data of 2015 (1313 kgs for native, $2725 \mathrm{kgs}$ for culture hybrid and $3869 \mathrm{kgs}$ for culture race) is noticed. The high yield advantage of culture race in meat and milk brings the requirement of specialising for the breeders in stock breeding. In a study carried out, Northeast Anatolia region, where the animal existence is the higher but applying traditional methods in breeding, and Western Marmara region, where livestock breeding is done with advanced technology and the average meat and milk yield is the highest, are selected to make an interregional comparison. It was found that the educational levels of the breeders in West Marmara region was higher than the educational levels of Northeast Anatolian breeders. It was indicated that this situation was a promoting factor for the breeders of the region to accept innovations more easily and it was an important parameter in the way of modern livestock breeding. It also stated in terms of supports that, breeders in Western Marmara region utilised artificial insemination, calf, forage plants and milk support more than the breeders in Northeast Anatolia region (Demir, 2009). In another study carried out in district Faisalabad of Pakistan. It was found that education level of women, income of household, age were significantly associated with level of participation. Women participation in livestock activities increased production and they were involved in income generating activities for better economic conditions of their families (Riasat et al., 2014).

In a study conducted on this subject in the literature, it was determined that the support provided for feed plant production had significant effects on the continuation of production, and in case the support for businesses in the region continues, clover and trefoil production will increase (Altıntaş et al 2017). Again, in a field study aimed to evaluate the relation of feed crops support with cattle livestock activities, it was determined that there was a significant relationship between the increase in the number of cattle and the number of the cattle owned by enterprises after they received feed crops support (Aksu and Dellal 2016). Again, in another study, the status of livestock breeding projects of the Ministry of Agriculture in Tokat Province before the application in 2005 and after the application in 2009 was examined. It was determined in the study that Breeding Cattle and Dairy Farming Projects positively affected cooperative organizations, and had significant effects especially on the increase of culture breed animal count (Şanl1 2011).

VECM Analysis: The panel data set consists a total of 1586 data in 6 variables, 26 cross-section data (286) in a 11-year period for each variable. As support payments per animal (brood cattle support) was started in 2009, the data of this variable is available for 6 years. It is understood that none of the variables show normal distribution with their coefficients of skewness and kurtosis according to the normal distribution (JarqueBera) test. Therefore, logarithmic transformation was applied to all the variables in the analyses of the study. Unit root tests to check the stationarity of the variables and cointegration tests as a measure of their liaising were applied in the model. According to the Levin et al. (2002), panel unit root tests, it was determined that the series are stationary when their primary differences are taken as ([1]). The maximum lag lengths of the series were selected automatically and based upon the Schwarz Information Criterion. Kao, (1999) cointegration analysis results which were used to investigate if the series, of which primary differences are taken and determined as stationary, are cointegrated in the long term. After the analysis it was seen that there is a relationship in the long term between animal existence and support payments of 26 sub-regions, which means they liaise. In other words, it can be said that the animal existence will respond to any variance in supports.

Lastly, it was analysed if there is a causality relationship between animal existence and support payments. It can be understood from the information above that there is a relationship between animal existence and support payments, but it is important to state statistically if this relationship is for short or long term. The long and short-term causality relationship between the variables are calculated by VECM. The relationship between the panel data set, which had been prepared with the data from 26 sub-regions for the period between 2004-2014, and each support item and animal quantities were tested separately. The long and short-term causality relationship between livestock support payments and animal existence was introduced with those tests (Table 3 ). 
Table 3. Causality Relationships Between Animal Existence and Support Payments.

\begin{tabular}{|c|c|c|c|c|c|c|}
\hline \multirow{2}{*}{$\begin{array}{c}\text { Causality } \\
\text { Relationships }\end{array}$} & \multicolumn{3}{|c|}{ Short Term Coefficients } & \multicolumn{3}{|c|}{ Long Term Coefficients } \\
\hline & $-0,25$ & $\leftrightarrow$ & $-0,01$ & $-0,95$ & $\leftrightarrow$ & -0.01 \\
\hline Animal Existence-Milk Support (AE-MS) & $-0,46$ & $\leftrightarrow$ & $-0,07$ & - & $\leftarrow$ & $-0,62$ \\
\hline Animal Existence-Feed Support (AE-FPS) & - & $\leftarrow$ & $-0,03$ & $-2,95$ & $\leftrightarrow$ & $-0,15$ \\
\hline Animal Existence-Brood Cattle Support (AE-BCS) & $-0,41$ & $\leftrightarrow$ & $-0,01$ & - & $\leftarrow$ & $-0,50$ \\
\hline Animal Existence-Total Support (AE-LBS) & $-0,49$ & $\leftrightarrow$ & $-0,03$ & $-1,02$ & $\leftrightarrow$ & $-0,08$ \\
\hline
\end{tabular}

Note: Statistically insignificant coefficients were not included. The other Coefficients are statistically significant at a level of $1 \%$.

According to the causality results, there are causality relationships between the total animal existence in Turkey and each analysed livestock support items for both short and long term. There is a two-way causality relationship between animal existence and all the support items except feed support in the short term. A two-way causality relationship between animal existence and all the support items except milk support and brood cattle support is found for the long term. The two-way relationship can be explained with the example of calf support item: any positive or negative movement in support payment will result a parallel change in animal existence, and vice versa.

This situation is true both for long and short term. The short term means a single production period. In that case, it will not be wrong to say that an increase in a single production period will cause animal existence to improve which ultimately accelerate support payment because any breeder can utilise the payments when he applies for the support items by meeting the conditions, which means additional budget when necessary. Similar relationships proceed in the long term with the regular continuity of the support payments.

Conclusion: The support payment for brood cattle, which was started in 2009 and adopted as basic support and paid as between 250-350 Turkish Liras per animal, has been revoked by the council of ministers' decision by the year of 2016 (Official Newspaper of Turkey, 2016). It can be said that the revoke is on point as there was a two-way causality relationship between animal existence and brood cattle support in the short term and it was a oneway causality relationship in the long term, because it is clear that geographically different regions have similar values in terms of animal existence, but they do not utilize support payments at the same ratio. It will not be wrong to say that the reason of western regions to have bigger shares in the payments is organised associations and county/province organizations as well as breeders of high consciousness and education level and high agricultural income.

Calf support, which has a two-way causality relationship with the animal existence in both short and long term, has gained the essence of being the basic support after the revoke of the brood cattle support. There was a necessity of artificial insemination and related conditions in calf support payments in 2015 and before. While there was a payment of 75 Turkish Liras for each calf born from artificial insemination and meat races, it has been specified in 2016 that any calf from any insemination will be paid 350 Turkish Liras with the condition of living at least 4 months in the enterprise they born and having scheduled vaccinations (Official Newspaper of Turkey, 2015; Official Newspaper of Turkey, 2016). It can be said that the revoke of the artificial insemination condition and breeders' getting 5 times more calf support payment will be beneficial for the breeder.

Feed support, which was identified to have a two-way relationship with the animal existence, is another important livestock support item. In Turkey, 30100 Turkish Liras of support payment has been paid to forage plant farmers for a decare of forage plant according to the variety of the plant. However, breeders find the payment insufficient and they expect a regulation about the feed prices or even getting feed support in kind.

In milk support, which has a two-way causality relationship with animal existence, there are no specific conditions for producers. The only provision is that by the year 2016, producers who do not perform contract production and get their contract recorded under milk recording system will not get raw milk support payment. This application is seen important for improving contract production and reducing fluctuations in milk prices.

To conclude, the study reveals that livestock support policies in Turkey create an acceleration in animal existence. However, ensuring the sustainability of animal production does not mean a mere increase in animal presence. Here, the basic issue is whether agricultural policies and supports provided for livestock, animal growth, development of animal count and breed, an increase of animal welfare, protection of resource base and minimizing production wastes will be a driving force in ensuring sustainable animal production. In this sense, it is very important to ensure the sustainability of livestock support policies in Turkey. The geographical conditions and the level of economic development of each region in the country must be considered, and special support items must be provided at the regional level. Payments must be categorized according to special conditions, and it must 
be made sure that modern production is realized as friendly to nature and the environment. In this sense, agricultural organizations and associations of growers/producers must be operated with strong inspection mechanisms to inform and organize producers.

Otherwise, the fact that livestock production does not increase fast enough to cover the needs of both the population of the country and the world and the growth in the production of animal products is a result of increased animal populations rather than largely increased productivity will not change.

\section{REFERENCES}

Aksu, N. and İ. Dellal (2016). An Evaluation for Afyonkarahisar Province on Relationship of Feed Crops Subsidy with Bovine Livestock Activities, Yüzüncü Yıl Uni. J. Agri. Sci. 26(1): 52-60

Altıntaş, G. A., Altıntaş and E. Çakmak (2017). Effect of Feed Plant Supports on Feed Plant Production (Sivas Province Example) J. Agri. Fac. Gaziosmanpasa Uni. 34(2): 116-127

Asteriou, D. and S.G. Hall (2007). Applied Econometrics: A Modern Approach Using Eviews and Micro Fit Revisited Edition, Palgrave Macmillan, New York.

Ata, N. and H. Yilmaz (2015). Reflections of Implementations of Livestock Production Support Polices On Dairy Farms in Turkey: The Case of Burdur Province, Suleyman Demirel Uni., J. Fac. Agri. 10(1): 44-54.

Babette, B., M. Lisett, and W. Maren (2019). Drivers of change and development in the EU livestock sector- Meta Analysis as basis for future scenario building. CWG-SAP - CASA study, EU Project No: 727486, 2019, Available online: https://era-

susan.eu/sites/default/files/Drivers $\% 20$ of $\% 20 \mathrm{ch}$ ange $\% 20$ and $\% 20$ development $\% 20$ in $\% 20$ the $\% 20$ EU\%20livestock\%20sector_BLE_CASA_STUD Y_0.pdf (accessed on 15 Dec 2019).

Baltagi B., H.H. Bai, and C. Kao (2000). Non Stationary Panels, Cointegration In Panels: A Survey, Center for Policy Research Working. Paper No:16. Available online: http://www.maxwell.syr.edu/uploadedFiles/cpr/p ublications/working_papers/wp 16.pdf (accessed on 10 Feb 2015).

Benin, S., S. Ehuiand, and J. Pender (2003). Policies for Livestock Development in the Ethiopian Highlands, Envi. Dev. Sus. 5(2): 491-510.

Daugbjerg, C., R. Tranter, P. Jones, J. Little, L. Costa, T. Knapp, M. Sottomayorand, and A. Swinbank (2005). The Visibility of Agricultural Subsidies and Market Illusions in the Common
Agricultural Policy: Some Evidence From Farmers' Views in Germany, Portugal and The United Kingdom, European J. Pol. Res. 44 (6): 749-766.

Demir, N. and F. Yavuz (2010). A Regional Comparative Analysis of Farmers' Approaches to Livestock Support Policies, J. Agri. Fac. Atatürk Uni. 41(2):113-121.

Demir, N (2009), Regional Comparative Analysis of The Effect of Support Policies on Livestock Sector, $\mathrm{PhD}$ Thesis (unpublished) Atatürk University Institute of Science, Erzurum.

Dogan, H. G. and B. Altuntas (2017). Searching Agricultural Policy Towards Problems and Solutions of Fattening Cattle Farms in Kırşehir Province Conditions (Case of Körpınar and Taşlitepe Villages), J. Fac. Karaman Econ. Admin. Sci. 19(32):55-64.

Ertuğrul, C (2000), Analysis of Support Policies in The Livestock Sector and Necessary Measures to Increase Production, Livestock 2000 congress-II, 21-22 November, Ankara, s. 100-107.

Food and Agriculture Organization of United Nations, FAO (2020). Animal production, Available online: http://www.fao.org/animalproduction/en/ (accessed on 04 April 2020).

Food and Agriculture Organization of United Nations, FAO (2014). Building a common vision for sustainable food and agriculture, E-ISBN 97892-5-108472-4 (PDF), Available online: http://www.fao.org/3/a-i3940e.pdf (accessed on 10 March 2017).

Food and Agriculture Organization of United Nations, FAO (2017). The future of food and agriculture, Trends and challenges, Available online: http://www.fao.org/3/a-i6583e.pdf (accessed on 10 June 2019).

Food and Agriculture Organization of United Nations Statistic, FAOSTAT (2019), Available online: http://www.fao.org/faostat/en/\#data (accessed on 15 March 2019).

Gültek, A (2000), Livestock Policies and Targets of the Ministry of Agriculture and Rural Affairs, Livestock 2000 congress-II, 31 March-2 April, Ankara, s. 77-87.

Im, K.S., M.H. Pesaran, and Y. Shin (2003). Testing for Unit Roots in Heterogeneous Panels, J. Econ. 115(1):53-74.

Kao, C. (1999). Spurious Regression and Residual-Based Tests for Cointegration in Panel Data, J. Econ. 90(1): 1-44.

Levin, A., C. Lin, and C.J. Chu (2002). Unit Root Tests in Panel Data: Asymptotic and Finite Sample Properties, J. Econ. 108(1):1-24.

Maddala, G.S.and S. Wu (1999). Comparative Study of Unit Root Tests With Panel Data and A New 
Simple Test, Oxford Bulletin of Economics and Statistics Special issue, 61(1): 631-652

Ministry of Food, Agriculture and Livestock of Turkey (MFAL) 2016. General Directorate of Agricultural Research Official sources.

Official Newspaper of Turkey (2015). Livestock Support About Application Notification, n. 2015/17 Available online: http://www.resmigazete.gov.tr/eskiler/2015/05/2 0150512-2.htm (accessed on 15 August 2015) .

Official Newspaper of Turkey (2016). Decision on Agricultural Supports to be made in 2016, n. 2016/8791. Available online: http:/www.resmigazete.gov.tr/eskiler/2016/05/2 0160505-3.pdf (accessed on 08 June 2016).

Ören, N., M.B. and Bahadır (2005). Livestock Policies and Policy Transfers in Turkey and OECD Countries, J. Animal Pro. 46 (1): 1-7.

Peker, K., M. Kan, and M. Nadeem (2019). Corporate governance of climate change adaptation. J. Glob. Innov. Agric. Soc. Sci. 7(1): 1-5.

Riasat, A., M.I. Zafar, I.A. Khan, R.M. Amir, and G. Riasat (2014). Rural development through women participation in livestock care and management in district Faisalabad. J. Glob. Innov. Agric. Soc. Sci. 2(1): 31-34.

Saghir, A., I. Ashraf, R. Kousar, and H. Tabassum (2016). Mitigating Migration Through Bridging Production Gap In Livestock Sector. J. Glob. Innov. Agric. Soc. Sci. 4(2):106-110.

Saman, M. R.M. Ghazala, O. Ghulam, and G. Shujaat (2017). Women Entrepreneurship: An Ultimate Remedy To Women Empowerment, Axhunger, Malnutrition, And Poverty. J. Glob. Innov. Agric. Soc. Sci. 5(4):181-187.

Steinfeld, H., P. Gerber, T. Wassenaar, V. Castel, M. Rosales, and C. Haan (2006). Livestock's Long
Shadow, Environmental issues and opsions, FAO. Available online: https://awellfedworld.org/wpcontent/uploads/pdf/UNGlobalWarmingReport.p df (accessed on 03 April 2020).

Şanl1, İ (2011). Impacts of Animal Husbandry Projects Launched by (MARA) Ministry of Agriculture and Rural Affairs on Organization of Cooperatives and Its Stakeholders. Master Thesis (unpublished), Gaziosmanpasa University, Graduate School of Natural and Applied Sciences, Tokat-Turkey.

Tan S., (2015). Agricultural Support Policies in Turkey, International Conference On Eurasian Economies, s. 266-270.

Turkey's Ministry of Finance (2016). General Directorate of Budget and Fiscal, Budget Realizations Reports. Available online: http:/www.bumko.gov.tr/TR,916/merkeziyonetim-butce-gerceklesmeleri-ve-beklentilerra-.html (accessed on 15 March 2016).

Turkish Statistical Institute, TURKSTAT (2015). Livestock Statistics,. Available online: http://www.tuik.gov.tr (accessed on 12 September 2015).

United Nations, UN (2019). World Population Prospects, Available online: https://population.un.org/wpp/ (accessed on 20 Dec 2019).

Zanten, H., O. Hal, and I. Boer (2016). Metrics, Models and Foresight for European Sustainable Food And Nutrition Security, SUSFANS Project No: 633692, Report, D4.1 Available online: https://susfans.eu/system/files/public files/Publi cations/Reports/SUSFANS (accessed on 10 May 2017) 